\title{
UNIVERSITASISASI STAIN MALANG: Analisis Kebijakan Publik Perubahan Kelembagaan Dalam Perspektif Filsafat Nilai
}

\author{
Muhammad In'am Esha \\ Fakultas Humaniora dan Budaya UIN Maulana Malik Irahim Malang \\ Jalan Gajaaya No.50 Malang. Telp: 08125245391 \\ email: essa_iesha@yahoo.com
}

\begin{abstract}
This paper examines to study institutional change of the State Islamic University (SIU), Malang. This study gets some summaries: First, that institutional change of SIU indicates that social sphere of higher education coloured with struggle for implementation of Islamic universality in education field. Struggle in social sphere of higher education cannot be discharged from spirit of Islam people to make a "more active" social sphere in Indonesia society. Spirit of universalization of Islamic values cannot be discharged from event pushing universitization of SIHE in the early $21 \mathrm{C}$. Second, successness of institutional change in SIU, Malang because: (a) its elite actors able to mobilize its modalities both economic, social, culture, symbolic, spiritual, political, and leadership capitals; (b) there is braveness from elit actors to put a window of opportunity as institutional actor for implementation of $\mathrm{MoU}$ between Minitry of Religious Affairs, Indonesia and Ministry of Education, Sudan by transform State of Islamic College of Malang (SICM) become Indonesia-Sudan Islamic University (ISIU). This Institutional change from SICM to ISIU, actually as an opportunity transformation from institutional problem toward international problem.
\end{abstract}

Tulisan ini mengkaji perubahan kelembagaan di UIN Malang. Kajian ini mendapatkan beberapa kesimpulan: Pertama, perubahan kelembagaan di UIN Malang menunjukkan bahwa ruang sosial pendidikan tinggi diwarnai dengan perjuangan untuk mengimplementasikan nilai-nilai universalitas Islam dalam ranah pendidikan. Perjuangan di ranah pendidikan tinggi tersebut tidak dapat dilepaskan dari spirit umat Islam untuk membuat sebuah ranah sosial 
yang "lebih aktif" dalam masyarakat Indonesia. Spirit universalisasi nilai-nilai keislaman tidak dapat dilepaskan dari hal hal yang mendorong perubahan Perguruan Tinggi Islam Negeri (PTIN) menjadi universitas. Kedua, keberhasilan perubahan kelembagaan di UIN Malang dipengaruhi oleh beberapa hal: (a) aktor-aktor elitnya berhasil memobilisasi modal yang dimiliki baik modal ekonomi, sosial, budaya, simbolik, spiritual, politik, maupun kepemimpinan; (b) adanya keberanian dari para aktor elit untuk mengambil "jendela peluang" untuk mengimplementasikan MoU antara Kementerian Agama RI dan Kementerian Pendidikan Sudan dengan mentransformasikan STAIN Malang menjadi Universitas Islam Indonesia-Sudan (UIIS). Perubahan institusional dari STAIN Malang menjadi UIIS sesungguhnya sebuah transformasi peluang dari persoalan kebijakan yang semula bersifat institusional menjadi persoalan kebijakan yang bersifat internasional.

Key words: social field, window of opportunity, change

\section{Pendahuluan}

Mengawali abad ke-21 terjadi perubahan yang sangat signifikan dalam konteks pengembangan pendidikan tinggi Islam di Indonesia berupa terjadinya perubahan kelembagaan beberapa PTAIN yang semula berstatus sebagai institut/sekolah tinggi menjadi universitas, tepatnya telah terjadi perubahan kelembagaan beberapa PTAIN yang semula berstatus IAIN/STAIN menjadi UIN. Dikatakan perubahan yang sangat signifikan tidak saja perubahan itu membawa dampak yang tidak kecil dalam konteks pergumulan pemikiran pendidikan Islam di Indonesia, tetapi perubahan itu juga membawa konsekwensi yang tidak kecil dalam ranah sosial, ekonomi, dan politik.

Beberapa PTAIN yang sudah berubah tersebut meliputi UIN Syarif Hidayatullah Jakarta yang semula IAIN Syarif Hidayatullah Jakarta, UIN Sunan Kalijaga Yogyakarta yang semula IAIN Sunan Kalijaga Yogyakarta, UIN Maulana Malik Ibrahim Malang yang semula STAIN Malang, UIN Sunan Gunung Djati Bandung yang semula IAIN Sunan Gunung Djati Bandung, UIN Alauddin Makasar yang semula IAIN Alauddin Makasar, dan UIN Syarif Kasim Riau yang semula IAIN Syarif Kasim Riau. Perubahan kelembagaan beberapa PTAIN tersebut juga diiringi oleh keinginan sejumlah IAIN untuk berubah menjadi UIN seperti yang saat ini sedang mengajukan proses perubahan tersebut adalah IAIN Sunan Ampel Surabaya dan sejumlah STAIN yang berubah menjadi IAIN seperti yang baru-baru ini diresmikan IAIN Surakarta. Tulisan ini mencoba untuk mencermati perubahan kelembagaan yang terjadi di STAIN Malang yang telah berhasil berubah bentuk kelembagaan menjadi 
UIN Malang pada tahun 2004 berdasarkan SK Presiden Nomor 50 Tahun 2004. Perubahan STAIN Malang menjadi sebuah Universitas Islam Negeri merupakan fenomena yang langka. Mestinya, kalau mau menggunakan teori perkembangan linier tentu perubahan itu harus berbentuk IAIN dahulu, tidak heran jika Prof. Azhar Arsyad menyebut perubahan kelembagaan di STAIN Malang sebagai quantum leap (Arsyad, 2011: 49).

Tulisan ini membahas tentang analisis kebijakan publik perubahan kelembagaan STAIN Malang menjadi UIN Malang dalam perspektif filsafat nilai. Filsafat nilai sengaja dijadikan perspektif dalam tulisan ini didasarkan pada pemikiran bahwa perubahan kelembagaan pada hakikatnya merupakan buah kebijakan atau keputusan yang diproduksi oleh pada aktor dalam sebuah medan sosial perjuangan dan keputusan yang diproduksi oleh para aktor tidak dapat dilepaskan dari nilai-nilai (values) yang melingkupinya (Bourdieu, 1993: 29). Nilai, dalam konteks Giddens, menjadi struktur yang mempengaruhi tindakan para aktor dalam pengambilan keputusan.

Persoalan yang menarik adalah apa nilai-nilai dasar perjuangan perubahan kelembagaan sehingga para aktor di lembaga ini berjuang untuk mengubah bentuk kelembagaannya menjadi universitas, bagaimana nilai-nilai tersebut diperjuangkan sehingga menghasilkan perubahan kelembagaan, dan bagaimana pasca perubahan kelembagaan tersebut nilai-nilai tersebut dikawal. Tiga hal itulah yang menjadi sesuatu yang menarik untuk dikaji. Kalau dicermati tiga persoalan tersebut, maka sebenarnya ketiganya itu merupakan pertanyaan filosofis. Pertanyaan pertama merupakan pertanyaan dalam aspek ontologi, yaitu apa nilai-nilai dasar sehingga mendorong perubahan kelembagaan. Pertanyaan kedua adalah aspek epistemologi, yaitu bagaimana nilai-nilai itu diperjuangkan dalam bentuk perubahan kelembagaan. Pertanyaan ketiga merupakan aspek aksiologis, yaitu bagaimana nilai-nilai dasar tersebut dikawal pasca perubahan. Oleh karenanya, perspektif yang digunakan dalam tulisan ini adalah filsafat nilai. Dalam tulisan ini, secara khusus akan lebih difokuskan pada aspek epistemologisnya yaitu bagaimana nilai berperan dan diperjuangkan dalam bentuk perubahan kelembagaan.

\section{Analisis Kebijakan Perubahan Kelembagaan dan Ranah Perjuangan 1. Model Analisis Kebijakan}

Terdapat beberapa model analisis kebijakan publik. Dalam konteks tulisan ini akan digunakan stream window model. Model ini berangkat dari pengandaian bahwa kebijakan yang dapat dilaksanakan haruslah dicapai 
setelah terbukanya "jendela" yang didorong oleh tiga arus besar. Pemikir yang mengenalkan model ini, tiga arus pembuka jendela itu meliputi: problems stream, political stream, and policy stream. Problem stream dimaksudkan masalah-masalah yang muncul dalam masyarakat yang perlu mendapat perhatian para pembuat kebijakan dan masyarakat. Political stream dimaksudkan sebagai bagaimana sebuah permasalahan itu mampu ditarik menjadi agenda pemerintah (Kingdon, 1984: 71).

Oleh karenanya, dalam konteks ini penting adanya kelompok-kelompok yang menekan pemerintah agar sebuah permasalahan dapat diangkat menjadi agenda pemerintah. Tetapi, ketika sebuah permasalahan itu memang sudah menjadi perhatian pemerintah maka biasanya 'pressure' semacam itu kurang diperlukan. Permasalahan tersebut sejalan dengan agenda atau 'mood' pemerintah. Sedangkan, policy stream merupakan upaya pelibatan pihak-pihak ahli dalam bidang permasalahan yang dihadapi tersebut baik dari para akademisi, peneliti, konsultan, staf kongres, pihak manajemen dan anggaran. Ketika tiga arus ini dipertemukan, maka barulah sebuah kebijakan dapat dihasilkan.

Model ini bermanfaat untuk menganalisis agenda latar (setting agenda) dalam proses pembuatan kebijakan, seperti yang dijelaskan Kingdon (Kelly, 2005: 9), dengan model ini dapat dianalisis tiga arus besar dalam perumusan kebijakan. Pada arus persoalan (problem stream) beberapa hal yang dapat ditelaah berkenaan dengan nilai-nilai yang berpengaruh dalam sebuah isu kebijakan. Dalam political stream, analisis dapat difokuskan terhadap kekuatankekuatan utama yang berpengaruh dalam formulasi agenda pemerintahan seperti kelompok kepentingan, perubahan-perubahan dalam pemerintahan, proses bargaining di antara kelompok-kelompok kepentingan, dan sebagainya. Analisis policy stream dapat difokuskan pada bagaimana argumen-argumen yang dibangun sehingga sebuah kebijakan dipilih di antara beberapa alternatif kebijakan yang muncul. Agar ide-ide kebijakan itu bertahan (survive) dan dapat diimplementasikan sangat dipengaruhi oleh fisibilitas teknis, akseptabilitas nilai, dan antisipasi terhadap keterbatasan-keterbatasan di masa depan ketika sebuah pilihan kebijakan itu dilaksanakan (Kingdon, 1984: 73).

Selain menggunakan stream-window model, kajian ini juga menggunakan model elit. Model kolaboratif dalam konteks penelitian ini menggunakan prinsip-prinsip dalam model elit dan model stream-window sehingga model ini bisa diistilahkan dengan stream-window elite model.

Dasar pemikirannya adalah bahwa dalam proses kebijakan yang terjadi di UIN Malang bersifat elit karena gagasan perubahan tersebut merupakan 
gagasan dari para elit baik lokal maupun nasional yang berada dalam suatu kontinum sistem tertentu untuk mengimplementasikan kebijakannya. Dalam proses implementasi tersebut, meminjam istilah Kingdon, para elit tersebut tidak bisa menafikan tiga arus dalam proses kebijakan yaitu: problem stream, political stream, dan policy stream.

Dalam kaitannya dengan problem stream pada prinsipnya berkenaan dengan konteks persoalan-persoalan yang muncul di masyarakat yang dirasakan oleh para elit masyarakat sehingga mendorong untuk dilakukan kebijakan tertentu. Dalam konteks ini pemahaman atas masalah menjadi hal yang tidak dapat dinafikkan. Teori gunung es (iceberg theory) dapat digunakan untuk memahami masalah kebijakan. Menurut teori ini, persoalan publik senantiasa diawali dari kejadian-kejadian yang nampak (events) di dalam masyarakat yang disebabkan oleh berbagai faktor. Berdasarkan kejadian-kejadian di masyarakat tersebut dapat memahami pola perilaku (pattern of behavior). Atas dasar pola prilaku tersebut, dapat memahami apa yang menjadi struktur sistemik (systemic structure) yang menjadi akar masalah tersebut (Widodo, 2008: 47).

Pemahaman terhadap masalah publik inilah yang pada gilirannya bisa mendorong munculnya kebijakan publik. Namun, demikian seperti dijelaskan oleh Islamy tidak semua permasalah publik akan berimplikasi pada lahirnya kebijakan publik (Islamy, 1997: 80). Islamy menegaskan bahwa suatu masalah publik bisa menjadi masalah kebijakan tidak cukup hanya dirasakan sebagai masalah publik, tetapi perlu ada political will untuk memperjuangkan problem umum tersebut menjadi problem kebijakan dan lebih penting lagi hal itu ditanggapi oleh para pembuat kebijakan. Dalam konteks ini, peranan elit masyarakat menjadi penting karena seringkali keprihatinan para elit masyarakat memunculkan political will dan mempengaruhi masyarakat sehingga masalah publik tersebut didorong untuk menjadi masalah kebijakan. Political and policy stream menjadi tahapan penting bagi munculnya sebuah kebijakan publik. Sebuah kebijakan dipengaruhi oleh window of opportunity yang dipengaruhi oleh tiga hal yaitu problem stream, political stream, dan policy stream (Kingdon 1984: 174). Window of opportunity ini yang nantinya akan berpengaruh pada outside initiative, mobilization, dan inside initiative. 


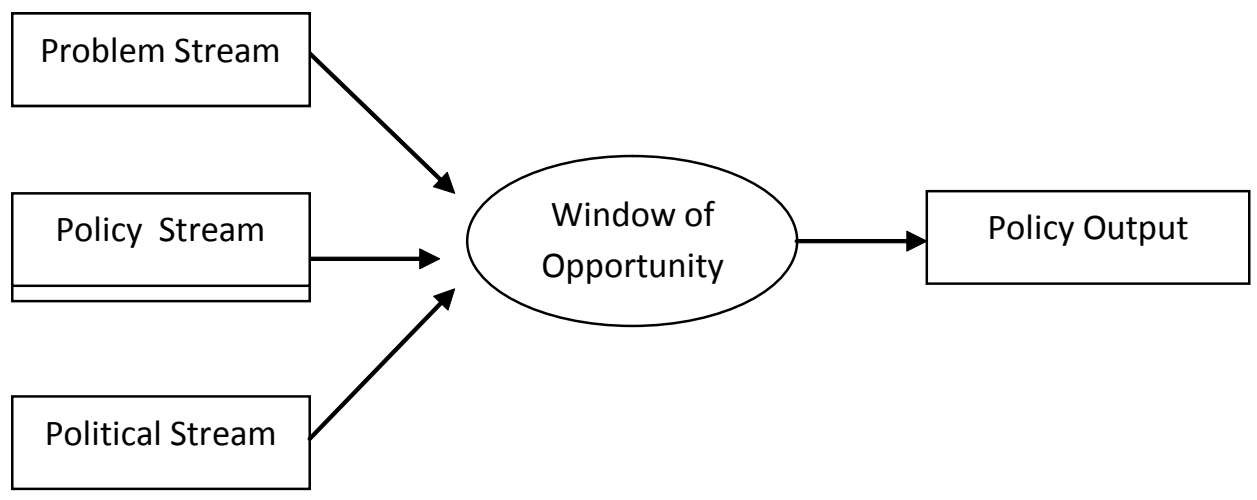

Gambar 1. Teori jendela peluang (Kingdon, 1984)

\section{Medan Sosial dan Arena Perjuangan}

Bourdieu menjelaskan bahwa dalam dunia sosial, dikenal medan sosial dan arena. Medan sosial mengacu pada keseluruhan konsepsi tentang dunia sosial. Konsep ini memandang bahwa realitas sosial sebagai suatu ruang (topologi). Medan sosial terdiri atas banyak arena yang saling terkait, tetapi memiliki mode sendiri. Arena adalah sebuah dunia sosial yang otonom dan bekerja dengan hukum-hukumnya sendiri. Misalnya mengenal arena politik, ekonomi, seni, agama, pendidikan, dan lain sebagainya. Setiap individu yang hendak memasuki sebuah arena, perlu memahami 'aturan main' di dalamnya.

Berkenaan dengan arena ini, dalam setiap arena terjadi apa yang disebut dengan pertarungan dalam rangka memperebutkan dominasi tertentu atau memperjuangkan nilai-nilai tertentu (Bourdieu 2010: 211). Nilai-nilai itu berusaha diperjuangkan yang pada gilirannya mampu membentuk sebuah dominasi-dominasi tertentu.

Dalam hal inilah penting untuk dibahas apa yang disebut dengan modal. Arena adalah bak pasar di mana semakin banyak modal yang dimiliki, kemungkinan memenangkan pertarungan dominasi menjadi sangat mungkin. Modal dimaksud dapat berupa modal ekonomi, sosial, budaya, maupun simbolik. Mereka yang tidak memiliki modal akan terjatuh dalam dominasi.

Modal merupakan energi sosial yang hanya ada dan membuahkan hasil dalam arena pertarungan di mana ia memproduksi dan mereproduksi. Modal sosial ialah hubungan-hubungan dan jaringan hubungan-hubungan yang merupakan sumber daya yang berguna dalam penentuan dan reproduksi 
posisi sosial (Haryatmoko, 2003: 11-12). Dalam konteks pendidikan, modal sosial ini dapat berupa jaringan alumni yang dimiliki oleh sebuah institusi pendidikan. Semakin banyak alumni sebuah institusi pendidikan menempati posisi-posisi penting dalam sebuah bangsa semakin kuat modalitas sosial yang dimiliki.

Modal budaya dapat berupa ijazah, pengetahuan yang sudah diperoleh, kode-kode budaya, cara berbicara, kemampuan menulis, cara pembawaan, sopan santun, cara bergaul, dan sebagainya yang berperan dalam penentuan dan reproduksi posisi sosial (Haryatmoko, 2003: 11-12). Dalam konteks pendidikan modal budaya ini bisa berupa produksi buku-buku yang dimiliki oleh sebuah lembaga pendidikan. Demikian juga dengan budaya akademik yang dibangun dan dikembangkan sebuah lembaga pendidikan tinggi. Semakin banyak produksi pengetahuan yang dimiliki oleh sebuah institusi menandai modal budaya akademik yang kaya bagi sebuah lembaga pendidikan.

Modal simbolik dapat berupa kantor yang luas di daerah mahal atau misalnya gelar pendidikan yang dicantumkan di kartu nama, bos dan ajudannya, dan sebagainya (Haryatmoko, 2003: 11-12). Dalam konteks pendidikan modal simbolik ini bisa berupa gedung yang megah, laboratorium yang lengkap, pelengkapan pendidikan yang lengkap, perpustakaan yang lengkap fasilitasnya, sertifikasi yang dimiliki, tingkat akreditasi BAN-PT, ISO, juga ranking pendidikan yang diperoleh oleh sebuah lembaga pendidikan tinggi. Kesemua itu murupakan modal simbolik yang penting dalam konteks ini.

Praktik sosial, dengan demikian, tidak dapat dilepaskan dari habitus, arena, dan modal/kapital. Praktik sosial dalam kenyataanya sarat dengan perilaku-perilaku bagaimana meneguhkan dominasi. Tidak heran jika kemudian Bourdieu ini tampil sebagai sosok yang melihat realitas sosial sebagai medan pertarungan individu dan kelompok-kelompok sosial satu dengan lainnya.

\section{Perubahan Kelembagaan STAIN Malang menjadi UIN Malang}

Mencermati proses kebijakan yang dialami oleh UIN Malang dari sebuah Sekolah Tinggi menjadi Universitas bisa dikatakan sebagai sesuatu yang 'istimewa'. Seperti yang dikatakan oleh Azhar Arsyad, Mantan Rektor UIN Alauddin Makasar, apa yang dialami oleh UIN Malang adalah sebuah quantum leap. Bahkan, Tafsir mengatakan apa yang dilakukan oleh Imam Suprayogo sebagai sesuatu yang ' gila'. Memang mestinya proposal perubahan yang diajukan adalah dari STAIN menjadi IAIN baru menjadi UIN. 


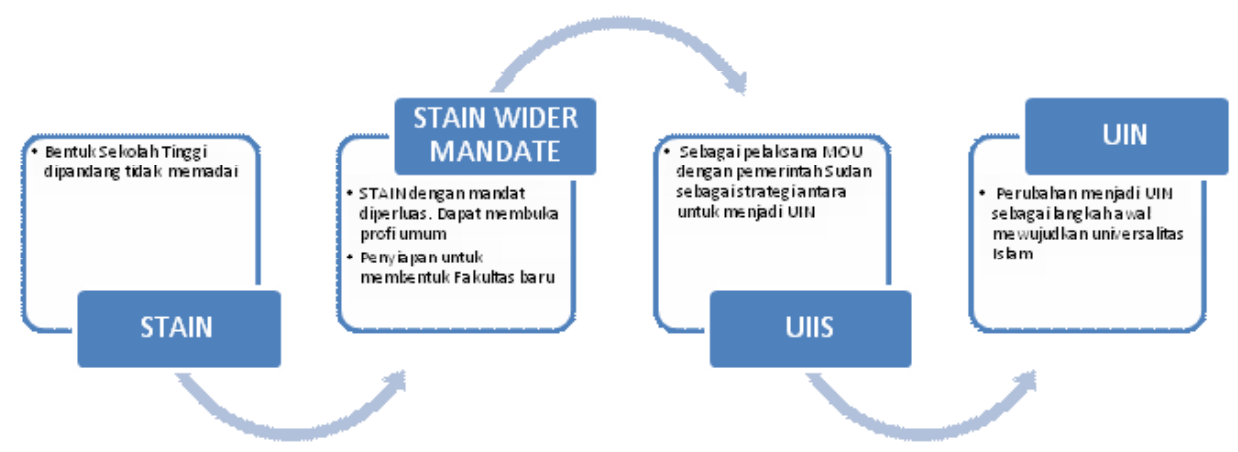

Gambar 2. Tahapan perubahan kelembagaan

Perubahan kelembagaan STAIN menjadi UIN menapaki tahapantahapan sebagai berikut:

a. Tahap pembangunan kesadaran

Tahap ini dilakukan misalnya dengan melakukan studi banding ke universitas-universitas Kristen untuk memberikan fakta empiris kemajuan lembaga pendidikan tinggi swasta Kristen. Melalui studi banding ini diharapkan akan muncul kesadaran akan ketertinggalan STAIN Malang dibandingkan dengan PTS lain.

Di samping itu, membangun kesadaran dilakukan melalui dialog-dialog non-formal tentang bagaimana memikirkan pengembangan kampus setelah menjadi STAIN Malang yang semula berbentuk Fakultas Tarbiyah cabang IAIN Surabaya. Sebagai STAIN bersifat otonom tidak lagi tergantung kepada IAIN induk oleh karena itu harus memikirkan pengembangan ke depan.

b. Tahap konsepsi dan perencanaan

Tahap konsepsi dan perencanan dilaksanakan dengan menyusun Rencana Strategis Pengembangan STAIN 10 Tahun ke Depan. Dalam Renstra ini dicanangkan bahwa selain pengembangan program-program strategis baik yang bersifat akademis, kelembagaan, dan ketenagaan, juga dalam waktu sepuluh tahun harus sudah berubah status menjadi universitas.

c. Tahap aktualisasi/implementasi

Tahap pelaksanaan didasarkan atas Renstra yang sudah disusun. Pada fase-fase awal dikembangkan program-program strategis seperti pengembangan Program Khusus Pembelajaran Bahasa Arab (PKPBA), perbaikan sarana dan prasarana, pembangunan Ma'had Aly, dan pengembangan jaringan kerjasama. Selain itu, terkait 
dengan rencana perubahan status kelembagaan terdapat beberapa hal yang dilakukan, yaitu: 1) Penyampaian usulan, pengembangan program strategis, dan STAIN Wider Mandate. Penyampaian usulan dalam bentuk proposal perubahan kelembagaan disampaikan secara terus-menerus tanpa kenal lelah. Pada tahapan inilah diplomasi dan komunikasi dilakukan secara intens oleh para aktor untuk menyakinkan banyak pihak, meskipun juga banyak yang 'menertawakan' bahkan ada yang menganggap bahwa apa yang dilakukan STAIN Malang sebagai sesuatu kegilaan.

Diplomasi dilakukan misalnya dilakukan oleh Imam Suprayogo tatkala ada rapat pembahasan perihal perubahan status kelembagaan IAIN menjadi UIN dan STAIN tidak menjadi agenda, tetapi, Imam Suprayogo meminta untuk diperkenankan hadir meskipun sebagai pendengar. Di samping itu, diplomasi melalui pendekatan personal juga dilakukan seperti menghadirkan tokohtokoh untuk mengenal lebih dekat STAIN Malang dan potensi strategisnya jika berubah menjadi universitas, diantara tokoh yang dihadirkan adalah Presiden Abdurrahman Wahid.

Komunikasi dibangun secara terus-menerus terutama kepada pihak internal kampus agar memahami 'mimpi' STAIN Malang menjadi UIN. "Saya memang pemimpi, agar mimpi itu jadi kenyataan maka saya akan mengajak semua orang untuk bermimpi”, demikian dikatakan oleh Imam Suprayogo. Komunikasi tidak hanya dilakukan secara verbal, tetapi juga secara tertulis dengan menerbitkan bukubuku yang dijadikan pedoman dalam pengembangan kampus seperti buku Visi, Misi, dan Tradisi, Tarbiyah Ulul Albab, Mimpi-mimpi STAIN Malang, dan Paradigma Pengembangan Keilmuan.

Di samping itu, STAIN Malang terus menerus melakukan pengembangan-pengembangan untuk mempersiapkan menjadi universitas. Secara akademik program-program strategis dikembangkan seperti Ma'had Aly dan Program Pascasarjana. Dalam rangka membuka program studi umum STAIN Malang memperoleh sebutan STAIN Wider Mandate, sehingga STAIN Malang yang semula hanya berupa pendidikan tinggi Islam yang membuka program-program studi agama dapat membuka programprogram studi umum. STAIN Malang dengan mandat diperluas ini merupakan hal strategis sehingga persiapan menuju universitas menjadi lebih lapang. 
2) Perubahan dari STAIN menjadi UIIS

Perubahan kelembagaan menjadi UIIS (Universitas Islam Indonesia Sudan) menunjukkan kepiawaian untuk memanfaatkan peluang untuk berubah menjadi Universitas. Perubahan menjadi UIIS ini menjadi 'strategis' antara yang bersifat blessing indisguise karena dengannya perubahan STAIN menjadi universitas menjadi kenyataan. Terlebih keberadaan UIIS peresmiannya dilakukan oleh Kepala pemerintahan kedua negara.

Ahad, 21 Juli 2002 merupakan hari bersejarah. Sebab pada hari itu, lembaga ini diresmikan menjadi universitas oleh Wakil Presiden RI, Dr. Hamzah Haz, disaksikan oleh Wakil Presiden I Sudan, Ali Osman Mohamed Taha dan sejumlah menteri, baik dari Indonesia maupun dari Sudan. Dua Menteri dari Indonesia yang hadir, Menteri Agama, Prof. Dr. H. Said Agil Husin al Munawwar, MA dan Menteri Pendidikan Nasional Prof. H. A. Malik Fadjar, M. Sc.

Penunjukan STAIN Malang oleh Menteri Agama sebagai pelaksana dari MoU itu didasarkan atas hasil evaluasi dan kajian yang dilakukan oleh tim yang ditunjuk oleh Menteri Agama dengan melibatkan beberapa orang baik dari Indonesia sendiri maupun Sudan. Beberapa IAIN dan STAIN dinominasikan untuk ditunjuk sebagai pelaksana MoU tersebut, tetapi akhirnya atas dasar pertimbangan hasil laporan tim dimaksud diputuskan STAIN Malang dianggap paling memenuhi syarat untuk menjadi universitas.

Beberapa kelebihan STAIN Malang di antaranya (1) memiliki program studi yang bervariatif (terutama terdapat beberapa program studi umum selain agama), (2) memiliki program khusus pengembangan Bahasa Asing (Arab dan Inggris) secara intensif, (3) memiliki ma'had (asrama mahasiswa) yang dapat menampung sejumlah besar mahasiswa, (4) berada di kota yang amat kondusif bagi pengembangan pendidikan tinggi, apalagi Malang dicanangkan sebagai kota pendidikan, (5) STAIN Malang memiliki perencanaan pengembangan baik fisik maupun akademik ke depan yang jelas. Oleh karena itu, sesuatu hal yang patut disyukuri, bahwa penunjukkan STAIN Malang menjadi universitas nampak sekali telah didasarkan oleh pertimbangan yang objektif, terbuka dan rasional. 
3) Perubahan dari UIIS menjadi UIN

Perubahan STAIN Malang menjadi UIIS ternyata menimbulkan persoalan diantaranya tidak diperkenankannya pencantuman negara asing menjadi nama perguruan tinggi di Indonesia. Karena itu nama UIIS harus diganti menjadi UIN berdasarkan Keppres No. 50/2004 yang sebelumnya didahului dengan adanya Surat Keputusan Bersama antara Menteri Agama dan Menteri Pendidikan Nasional.

Mencermati proses perubahan kelembagaan STAIN Malang menjadi UIN Malang menampakkan sesuatu yang menarik dimana dalam kasus ini proses kebijakannya bersifat bottom-up. Ini tentu berbeda dengan IAIN Syarif Hidayatullah dan IAIN Sunan Kalijaga Yogyakarta yang bersifat top-down karena melaksanakan rencana kebijakan pemerintah pada masa Menteri Agama dijabat oleh Tarmidzi Taher (Rasmianto, 2004: 36).

\section{Analisis Kebijakan Universitasisasi STAIN Malang}

Mencermati perubahan kelembagaan yang terjadi di UIN Malang memberikan pemahaman bahwa peranan aktor elit sangat menentukan. Tidak salah jika dikatakan bahwa perubahan yang terjadi di UIN Malang merupakan kebijakan elit-massa (Wahab, 2008: 88). Para aktor elit kampus dengan posisi dan kewenangan yang dimiliki menggagas dan menggulirkan perubahan kelembagaan.

Kesadaran akan pentingnya kemajuan PTAIN sudah menjadi kesadaran di kalangan elit kampus tatkala masih berstatus sebagai Fakultas Tarbiyah IAIN Sunan Ampel Malang. Persoalannya adalah kenapa perubahan itu baru terjadi pada masa tertentu dan di bawah elit tertentu? Ambillah contoh misalnya kesadaran bahwa mahasiswa PTAIN sudah seharusnya memahami bahasa Arab sebagai kompetensi yang utama karena PTAIN didirikan sebagai jembatan untuk mengkaji sumber ilmu yang berasal dari al Quran dan Hadits yang berbahasa Arab. Kenyataan bahwa kualitas penguasaan bahasa Arab di kalangan mahasiswa PTAIN menurun. Dapat dipahami bahwa kesadaran akan sebuah masalah ternyata tidak serta merta mampu melahirkan tindakan (policy) tertentu.

Keberhasilan STAIN Malang berubah menjadi UIN Malang adalah ditentukan oleh keberanian elitnya untuk memanfaatkan jendela peluang (window of opportunity) yang ada. Kesempatan untuk menjadi pelaksana MoU 
antara Kementerian Agama RI dan Kementerian Pendidikan Sudan. Tatkala Wakil Pemerintah Sudan yang rencananya hendak berkunjung ke Indonesia, maka moment itu dimanfaatkan untuk melakukan peresmian STAIN Malang menjadi UIIS.

Jendela peluang dimanfaatkan oleh para aktor elit untuk melakukan mobilisasi (mobilization) dalam mencapai tujuan (Kingdon, 1995: 165), sebagaimana yang telah rencanakan dalam RSP STAIN Malang. Momentum tersebut diperkuat dengan spirit progresif di kalangan elit kampus UIN Malang dalam mencermati kondisi kampus STAIN Malang yang seperti 'SD Inpres' di satu sisi dengan kondisi masyarakat luas dengan berbagai harapan kepada pendidikan tinggi Islam dan tantangannya di sisi lain merupakan realitas yang harus dijadikan momentum untuk melakukan perubahan. Spirit untuk mengejawantahkan nilai-nilai universalitas Islam dalam ranah pendidikan tinggi Islam menjadi hal yang mendasari perjuangan perubahan kelembagaan tersebut.

Dalam fenomena perubahan kelembagaan di UIN Malang dapat dipahami bahwa kesadaran aktor elit atas persoalan yang dihadapi (elits problems) mampu ditransformasikan menjadi perubahan institusional (institutional problems). Hal ini diwujudkan dalam bentuk Rencana Pengembangan Strategis STAIN Malang 10 Tahun ke Depan. Secara nasional, kebijakan perubahan kelembagaan menjadi UIN telah menjadi kebijakan pemerintah, hanya saja STAIN Malang tidak menjadi 'target'. Karena itulah, aktor elit menjadikan momentum kerjasama Departemen Agama RI pada saat itu dengan Departemen Pendidikan Sudan untuk menarik institusional problem tersebut menjadi masalah dan isu publik (publik issue) sekaligus menjadi masalah dan isu politik (political issue). Perubahan STAIN Malang menjadi UIIS telah membawa STAIN Malang menjadi isu nasional dan sekaligus internasional karena melibatkan hubungan antarnegara. Pada titik ini, perubahan kelembagaan STAIN Malang yang semula dipandang sebelah mata, menjadi perhatian publik dan negara (state). 


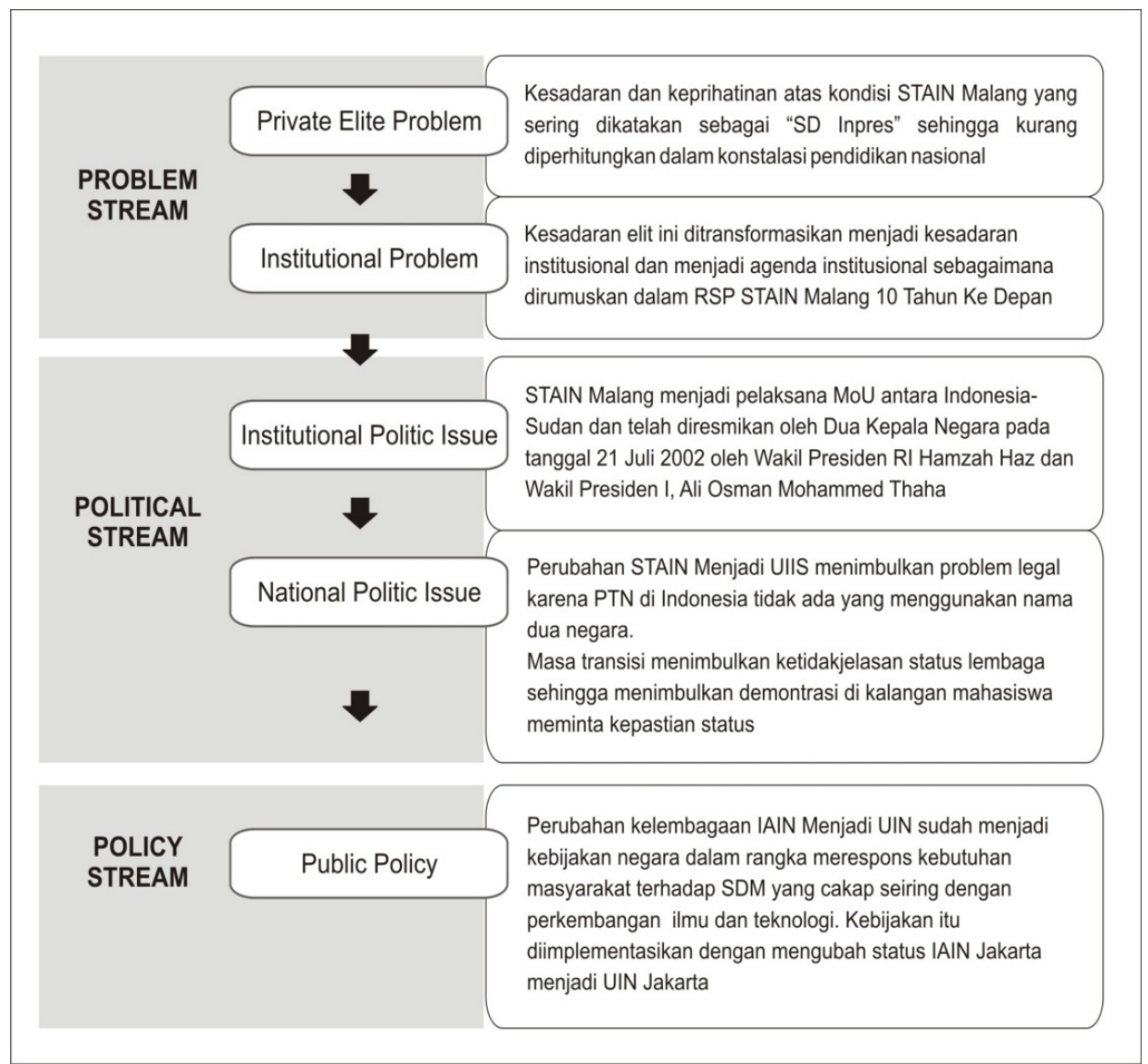

Gambar 3. Stream-Window Elite Model dalam Proses Perubahan Kelembagaan

Permasalahannya adalah bagaimana sebuah momentum tersebut mampu dimanfaatkan dengan baik. Adalah akan sulit meskipun ada momentum kalau sebuah lembaga itu tidak memiliki daya dukung yang memadai. Di sinilah pentingnya pendayagunaan modal untuk merebut dan memenangkan pertarungan dalam medan sosial perubahan kelembagaan (Bourdieu, 2010: 215).

Dalam proses perubahan STAIN Malang menjadi UIN Malang setidaknya dapat dikategorikan modalitas yang digunakan untuk mendukung keberhasilan dalam proses perubahan tersebut, yaitu:

Pertama, modal ekonomi (economic capital). Modal ekonomi dipahami sebagai modal yang didasarkan pada pemilikan seseorang atau kelompok dalam hal ekonomi. Modal ekonomi ini biasanya tersimpul dalam seberapa 
besar jumlah uang atau kekayaan yang dimiliki oleh seseorang atau sebuah kelompok misalnya sebuah organisasi, perusahaan, dsb. UIN Malang saat berstatus STAIN Malang kondisi keuangannya masih sedemikian minim. "Kami karena keterbatasan dana pada saat itu harus menumpang kereta untuk pergi ke Jakarta karena keterbatasan dana yang dimiliki”, demikian penuturan Baharuddin, mantan Pembantu Ketua II STAIN Malang.

Keterbatasan dana ini tidak menjadi halangan untuk mengembangkan kelembagaan. Berbagai strategi dilakukan untuk menggalang pendanaan dari masyarakat seperti membentuk Ikatan Orangtua Mahasiswa (IKOMA). Melalui IKOMA ini diperoleh dana yang relatif besar untuk beaya pengembangan kampus. Pada tahun 2008/1999-1999/2000 melalui IKOMA berhasil dikumpulkan dana sebesar Rp. 635.955.000,-(Enam Ratus Tiga Puluh Lima Juta Sembilan Ratus Lima Puluh Lima Ribu Rupiah). Sebuah angka yang sangat besar untuk ukuran STAIN Malang yang baru berubah dari status lamanya, Fakultas Tarbiyah IAIN Sunan Ampel Malang. Dana ini digunakan untuk pembangunan sarana dan prasarana kampus seperti ma'had al jami'ah (pesantren kampus). Dalam rangka memberikan akuntabilitasnya, setiap tahun dilakukan pertemuan dengan orang tua wali mahasiswa untuk memberikan laporan penggunaannya.

Kedua, modal budaya (culture capital), termasuk dalam modal budaya pengetahuan yang sudah diperoleh, kode-kode budaya, cara berbicara, kemampuan menulis, cara pembawaan, sopan santun, cara bergaul, dan sebagainya yang berperan dalam penentuan dan reproduksi kedudukan-kedudukan sosial (Bourdieu, 2010: 24). Dalam konteks di UIN Malang, modal budaya akademik merupakan hal yang penting dalam proses perubahan kelembagaan.

STAIN Malang pada saat itu mengembangkan program-program strategis untuk mengembangkan budaya akademik di kampus, yaitu:

1. Pengembangan budaya akademik berbahasa Arab. Kegiatan ini digulirkan sejak tahun 1997/1998 melalui Program Khusus Pengembangan Bahasa Arab.

2. Pengembangan Pesantren Kampus untuk menyelenggarakan berbagai kajian kitab kuning dan pembiasaan berbahasa Arab dan Inggris.

3. Membentuk pusat-pusat kajian sebagai wadah pengembangan keilmuan meliputi Pusat Studi Gender (PSG), Lembaga Kajian Agama dan Masyarakat Kota (LKAMK), Pusat Penerbitan, Penelitian, dan Pengabdian kepada Masyarakat (P3M).

4. Pengembangan kerjasama dengan lembaga di dalam dan luar negeri 
dalam rangka pengembangan akademik seperti dengan Arab Saudi dan Australia.

5. Program studi yang sangat variatif baik yang program studi ilmu keislaman dan juga keilmuan lain seperti MIPA, Psikologi, dan Ekonomi.

6. Mendirikan Program Pascasarjana di STAIN Malang.

Ketiga, modal sosial (social capital). Modal sosial dipahami sebagai norma informal yang dapat meningkatkan kerjasama antara dua orang atau lebih. Bentuk dan wujud nilai tersebut dapat berupa nilai-nilai atau norma hubungan timbal balik dan juga dapat berupa berbagai doktrin yang lebih kompleks. Termasuk dalam modal sosial ini, menurut Haryatmoko adalah hubunganhubungan dan jaringan-jaringan yang merupakan sumberdaya yang berguna dalam penentuan reproduksi kedudukan-kedudukan sosial (Haryatmoko, 2003: 11-12). Modal sosial (social capital) yang didayagunakan dalam konteks perubahan kelembagaan adalah jaringan-jaringan yang dimiliki oleh pada elit kampus di UIN Malang merupakan modal sosial penting dalam proses perubahan kelembagaan.

Keempat, modal simbolik (symbolic capital). Modal simbolik tidak lepas dari kekuasaan simbolik, yaitu kekuasaan yang memungkinkan untuk mendapatkan setara dengan apa yang diperoleh melalui kekuasaan fisik dan ekonomi, berkat akibat khusus suatu mobilisasi. Modal simbolik STAIN Malang yang penting dalam konteks ini adalah kemampuan STAIN Malang mewujudkan Program Bahasa Arab di sebuah PTAIN yang selama ini hanya menjadi keprihatinan dari satu menteri ke menteri yang lain dan kemampuan STAIN Malang mendirikan Pesantren Kampus (Ma'had al Jami'ah). Dua hal inilah yang menjadikan STAIN Malang saat itu menjadi perbincangan secara nasional dan akhirnya banyak PTAIN yang berguru ke STAIN Malang saat itu.

Modalitas inilah yang kemudian dimobilisasi dalam proses perubahan kelembagaan di UIN Malang. Berkat modalitas yang dimiliki tidak mengherankan jika STAIN Malang pada saat itu dipercaya untuk melaksanakan MoU antara Departemen Agama RI dengan Kementerian Pendidikan Sudan. STAIN Malang pada saat itu dipandang sebagai lembaga yang memenuhi syarat untuk menjadi pelaksana MoU tersebut yaitu menjadi Perguruan Tinggi Kerjasa antara Pemerintan Indonesia dengan Sudan.

Modalitas lain yang dapat dipahami dalam konteks ini adalah modalitas spiritual, modalitas politik, dan modalitas kepemimpinan. Modal spiritual 
dimaksudkan sebagai kemampuan untuk mengembangkan hal hal yang bersifat spiritual. Termasuk dalam modal spiritual adalah doa bersama, khatm al Quran, tradisi puasa senin-kamis, qiyamullail, shalat berjama'ah, riyadhah kubro, dan tradisi menghajikan dosen. Hal menarik yang perlu dipaparkan di sini adalah bahwa biasanya tatkala ada warga kampus yang naik haji pasti diminta untuk mendoakan kampus.

Modalitas politik (political capital) adalah sumber (resource) yang dimiliki oleh pelaku atau sebuah lembaga untuk menghasilkan tindakan yang menguntungkan atau memperkuat posisi pelaku atau lembaga tersebut. Modalitas politik dalam konteks ini adalah secara kelembagaan STAIN Malang adalah kuat terutama sejak terbitnya Keppres No. 11/1997 yang mengubah status Fakultas Cabang IAIN menjadi STAIN. Modalitas politik semacam ini memungkinkan sebuah lembaga untuk mengambil inisiasi tanpa terhambat oleh institusi induknya.

Modalitas Kepemimpinan (leadership capital). Modal kepemimpinan dimaksudkan dengan kemampuan untuk menggerakkan dalam rangka mencapai visi ke depan yang telah disepakati. Perubahan kelembagaan di UIN Malang ini menunjukkan bahwa modalitas kepemimpinan juga memegang peranan yang penting. Elit kampus yang memimpin STAIN Malang memiliki modalitas kepemimpinan yang memungkinkan untuk melakukan gerakan perubahan.

Terdapat pilar-pilar kepemimpinan yang diterapkan dalam masa perubahan STAIN Malang menjadi UIN Malang yaitu: (1) mengakui akunya semua pihak, (2) memberikan harapan-harapan baik harapan pribadi maupun kelompok, (3) menghilangkan rintangan, (4) membagi cinta secara merata, (5) membagi informasi secara luas, (6) membangun kepercayaan diri lewat pengakuan kalangan secara luas, (7) adil dan jujur serta mampu bertindak tegas, (8) mengayomi semua, (9) aspiratif untuk semua, (10) membangun cita dan tekad bersama, (11) menyalurkan aspirasi dan bukan memotong, (12) membangun budaya berpuasa, (13) mengedepankan musyawarah dan saling menasehati, (14) berorientasi kesamaan dan kebersamaan, dan (15) menciptakan inovasi baru secara terus-menerus (Suprayogo, 2009: 41).

\section{Simpulan}

Dalam perspektif filsafat nilai, dapat dicermati bahwa perubahan yang terjadi pada fenomena perubahan kelembagaan STAIN menjadi UIN tidak dapat dilepaskan dari nilai. Perubahan status kelembagaan STAIN menjadi 
UIN bukan semata perubahan papan nama. Tetapi, kata 'Universitas Islam Negeri' mengandung peristiwa yang sedemikian besar yaitu sebuah keberhasilan awal dari perjuangan untuk lebih memberikan makna bagi keberadaan PTAIN di masa depan (future value).

Universitasisasi merupakan buah perjuangan panjang agar pendidikan tinggi Islam mampu mengemban tugas secara lebih leluasa di dalam membangun masyarakat Islam di masa mendatang. Meskipun tidak dapat dielakkan bahwa spirit perubahan tersebut secara ultimate disandarkan untuk mewujudkan nilainilai Islam yang bersifat universal melalui sebuah lembaga pendidikan tinggi Islam yang selama ini dipandang terlalu sesak tatkala bentuk kelembagaan berupa Sekolah Tinggi.

\section{Daftar Pustaka}

Abdul Wahab, Solichin. 2008. Pengantar Analisis Kebijakan Publik. Malang: UMM Press.

Arsyad, Azhar. 2011. "the Real Khalifah" dalam Barizi dan Mujtahid (ed.), Membangun Pendidikan Islam dalam Bingkai Islam Lintas Batas Malang: UIN-Maliki Press.

Bourdie. Pierre. 1993. The Field of Cultural Production. Columbia: Columbia University Press.

Bourdieu, Pierre. 2010. Arena Produksi Kultural: Sebuah Kajian Sosiologi Budaya. Yogyakarta: Kreasi Wacana.

Haryatmoko. 2003. "Menyingkap Kepalsuan Budaya Penguasa" dalam Basis: Nomor 11-12 Tahun Ke-52, November-Desember.

Islamy, M. Irfan. 1997. Prinsip-prinsip Perumusan Kebijaksanaan Negara. Jakarta: Bumi Aksara.

Kelly, Brendan. 2005. "John Kingdon's Theory at the State Level: A Look at Preschool for All in Illinois and California”. Paper.

Kingdon, John W. 1984. Agendas, Alternative, and Public Policies. Boston: Little Brown.

Kingdon, John W. 1995. Agendas, Alternative, and Public Policies, $2^{\text {nd }}$ Edition. New York: Harper Collins. 
Rasmianto, Muhammad In'am Esha, dan Eko Suprayitno. 2004. Proses Perubahan STAIN menjadi UIN Malang dalam Rekaman Media. Malang: UIN Malang Press.

Suprayogo, Imam. 2009. Universitas Islam Unggul: Refleksi Pemikiran Pengembangan Kelembagaan dan Reformulasi Paradigma Keilmuan Islam. Malang: UIN Malang Press.

Widodo, Joko. 2008. Analisis Kebijakan Publik. Malang: Bayu Media. 